\title{
A survey on Italian compost dairy barns
}

\author{
Lorenzo Leso, ${ }^{1}$ Maurizio Uberti, ${ }^{2}$ Wasseem Morshed, ${ }^{1}$ Matteo Barbari ${ }^{1}$ \\ ${ }^{1}$ Departement of Agricultural, Food and Forestry Systems, University of Florence, Italy; \\ ${ }^{2}$ Freelance veterinarian
}

\begin{abstract}
Compost-bedded pack barns, generally known as compost dairy barns, are alternative housing systems for dairy cows. In these barns, the whole surface of the resting area is covered with a deep-bedded pack that is frequently stirred in order to incorporate fresh manure into the pack and to enhance the evaporation of water. Experiences with compost bedded pack barns for dairy cows are reported in literature from the USA, Israel, the Netherlands and Austria. The main advantages of these housing systems regard animal welfare and manure management. Since 2006, this housing system has been applied consistently in Italy. However, scientific knowledge about Italian compost barns is still lacking. This study aims at describing housing system, assessing producers' satisfaction and measuring performance of dairy cows housed in compost bedded pack barns. Ten commercial dairy farms in northern Italy was involved in the study. All pens in each farm were surveyed to determine the surface of total available area, bedded area and pack depth. In order to investigate management practices, labor requirement, consumption of bedding materials and producers satisfaction, a questionnaire was submitted to each farm manager. The temperature of the bedded pack was measured in each farm during summer and winter. Moreover, data from Italian Breeder Association were collected for each herd over a period of one year (from September 2011 to September 2012). For the ten compost barns involved in the study the average total available area was $10.9 \mathrm{~m}^{2}$ per cow and the average pack area was $6.7 \mathrm{~m}^{2}$ per cow. The bedded pack was aerated 1.4 times per day. The most commonly used bedding material in these farms was dry sawdust. The consumption of bedding materials was $8.1 \mathrm{~m}^{3}$ per cow per year. A clear tendency to inverse correlation was found between the space per cow and the amount of bedding needed per cow $\left(\mathrm{R}^{2}=0.395\right.$; $\mathrm{p}$-value $=0.051$ ). Operations related to pack management require 4.1 hours of labor per cow per year. Direct relationship was found between the bedded area space per cow and the annual labor required for pack
\end{abstract}

Correspondence: Matteo Barbari, Departement of Agricultural, Food and Forestry Systems. University of Florence, Italy

E-mail: matteo.barbari@unifi.it

Acknowledgements: the authors wish to thank all the dairy producers for their kind collaboration. We also acknowledge the Associazione Italiana Allevatori and the APA of Mantua and Cremona for their important contribution in providing data.

(C) Copyright M. Barbari et al., 2013

Licensee PAGEPress, Italy

Journal of Agricultural Engineering 2013; XLIV(s2):e40

doi:10.4081/jae.2013.s2.e40

This article is distributed under the terms of the Creative Commons Attribution Noncommercial License (by-nc 3.0) which permits any noncommercial use, distribution, and reproduction in any medium, provided the original author(s) and source are credited. management per cow $\left(\mathrm{R}^{2}=0.505\right.$; $\mathrm{p}$-value $\left.=0.048\right)$. Performance of cows housed in compost barns included in this study was encouraging and although some concerns about the cost of bedding, overall producers were satisfied with this housing system.

\section{Introduction}

Compost-bedded pack barns, generally known as compost dairy barns, are an alternative loose housing system that appears to offer excellent comfort level for dairy cows. In this type of barn, cows are provided with a large bedded area for resting rather than individual stalls. Compost bedded pack refers to a mixture of feces and urine produced by the cows and organic bedding. Unlike conventional strawbedded yards, the whole surface of compost packs is cultivated once or twice daily to dry the surface and incorporate manure into the pack (Klaas and Bjerg, 2011). A properly managed bedded pack provides a dry, comfortable and healthy surface on which cows lie, stand and walk. Compost-bedded pack barns for dairy cows are spread in the USA, Israel, Europe and South Korea (Galama, 2011). By analyzing international literature two main types of compost-bedded pack barns could be identified. Although both two types seem to be based on the evaporation of water from the pack, management practices, type of bedding materials and barn's characteristics are significantly different (Galama 2011; Klaas and Bjerg, 2011).

The first type, which was initially developed in the USA and applied with some modifications also in the Netherlands and Austria, is based on the development of heat in the pack. In this type of compost barns the most important issue is to maintain adequate chemical and physical characteristics into the substrate in order to promote aerobic microbial activity (Black et al., 2013). The recommended bedded area space per cow for this type of housing system ranges from 7.4 to 12.5 $\mathrm{m}^{2} /$ cow (Janni et al. 2007; Galama, 2011; Black et al., 2013). The most commonly used bedding materials are sawdust, wood shavings and wood chips. The second type of compost barn takes advantage from the natural drying potential of the air rather than heat production into the pack (Galama, 2011). This type of housing system has been developed in Israel and is receiving an increasing interest in the Netherlands. The recommended bedded area space per cow in this type of compost barns ranges from 15 to $20 \mathrm{~m}^{2} / \mathrm{cow}$ in barns provided with scraped feeding alleys and up to $30 \mathrm{~m}^{2} / \mathrm{cow}$ in systems without concrete alleys (Klaas et al., 2011).

Since 2006, compost-bedded pack barn for dairy cows has spread in Italy. Actually, Italian compost dairy barns are about 50, mostly located in the Po Plain, northern Italy. Although in other countries this housing system has evolved mainly with the aim of increasing the welfare of dairy cows (Barberg et al., 2007a; Klaas et al., 2010), in Italy it was developed initially to reduce the risk of mastitis in deep straw-bedded yards. Compost bedded pack was quickly appreciated by Italian farmers for its benefits towards udder health (Vighi et al., 2009). Few years later, also the positive effects on lameness prevalence and longevity became evident and many more farmers shifted to compost bedded pack. 
As a matter of fact, one of the most noticeable benefits of compost bedded pack regards cow comfort and feet and legs health (OfnerSchröck et al. 2013; Barberg et al., 2007b; Fulwider et al., 2007; ). Lobeck et al. (2011) found that dairy cattle housed in compost bedded barns had reduced lameness and hock lesions compared with those housed in free stall barns. Observations of lying behavior, social interactions, and natural lying positions indicated that compost dairy barns could be an adequate housing system for dairy cows (Enders and Barberg, 2007). Overall, producers are satisfied with this housing system, especially for improved animal welfare, but some concerns regard pack management and the cost and availability of bedding (Shane et al., 2010).

Besides the benefits mentioned above, this alternative housing system could represent an effective tool to reduce the costs for manure management, especially in areas where there is a high density of dairy production, such as Po Plain, Italy. Compared with free stall barns, compost bedded pack barns produce less slurry, and solid manure has higher agronomic value (Galama, 2011). The interest of Italian farmers and researchers towards compost dairy barns is rapidly and consistently increasing (Ventura, 2011). However, scientific knowledge about the application of this housing system in Italy is still lacking. The objective of the current study was to describe housing system and management practices, assess producers satisfaction and measure performance of dairy cows housed in Italian compost-bedded pack barns.

\section{Materials and methods}

This observational study was performed on ten dairy farms in the provinces of Mantua (n. 7) and Cremona (n. 3). All farms included met the following criteria: shifted to compost bedded pack at least two years before the start of the study, all lactating cows are housed in compost bedded pack barns, pack is cultivated at least once per day, drivethrough TMR feeding and use corn silage in lactating cows' ration. The primary breed in all farms was Holstein. Monthly dairy herd records were obtained from Italian Breeders Association (Associazione Italiana Allevatori, www.aia.it) for each farm included. To assess herds' performance the following data were collected over a period of one year (from September 2011 to September 2012): herd mean daily milk yield, 305 mature equivalent milk production, days in milk (DIM), fat and protein content, herd mean somatic cells count (SCC), age at first calving, mean number of parity, calving interval and mean number of services per pregnancy.

Each farm was visited once between July and September 2012 to collect on-farm data which included: barn dimensions and layout, total available area space per cow, lying area space per cow, bedding type and pack depth. Barns dimensions was measured using a Leica DISTO A5 laser distance meter (Leica Geosystems, Heerburgg, Switzerland). A questionnaire was submitted to the herd manager at the time of the visit. The first part of the questionnaire included 25 questions regarding pack management practices, machines and equipment used, labor required and consumption of bedding. In the second part of the questionnaire producers were asked to express their satisfaction with the alternative housing system in regards to the following features: animal welfare, cow cleanliness, udder health, claw and leg health, fertility, longevity, milk yield, ease of management, costs and manure management. Satisfaction levels was expressed using a 4-point scale where $1=$ very dissatisfied, $2=$ dissatisfied, $3=$ satisfied and $4=$ very satisfied.

In addition, five farms were visited twice, once in winter (January 2012) and once in summer (August 2012), to measure the temperature of the pack and the air temperature inside the barn. Pack temperatures were taken in ten points across the resting area at $20 \mathrm{~cm}$ depth. Air temperature was measured in five positions inside the barn at $1 \mathrm{~m}$ above the pack surface. Temperature measurements were performed by the same operator using a D0 9847 portable multifunction data-logger (Delta Ohm, Padua, Italy).

\section{Statistical analysis}

Descriptive statistics (mean, SD and range) were used to describe herds' characteristics, spaces per cow, pack depth, pack temperatures, air temperatures, quantitative data regarding management practices and producers' satisfaction scores. Results are presented in text as mean \pm SD and range. Linear regression analyses were performed to identify variables affecting consumption of bedding and labor requirement. Residuals were visually checked. Coefficient of determination $\left(\mathrm{R}^{2}\right)$ was calculated to assess the goodness of fit of the model and t-test were performed to determine whether there is a significant linear relationship between variables. All analyses were performed using the "base" and "stats" packages of R (R Development Core Team, 2011).

\section{Results}

The size for the herds included in this study was $112 \pm 58.8$ lactating cows ranging from 42 to 192 . Descriptive statistics for the herds' performance are reported in Table 1. All the compost barns visited had a flat concrete floor under the bedded pack and nine out of ten barns have an indoor (n. 6) or outdoor (n. 3) scraped feed alley. The width of the feed alleys resulted in $4.32 \pm 1.54 \mathrm{~m}$ while the space per cow at the feed fence was $0.58 \pm 0.20 \mathrm{~m} / \mathrm{cow}$. In one barn there was no scraped alley. Total available area space per cow was $11.0 \pm 4.1 \mathrm{~m}^{2} / \mathrm{cow}$. The resting area (compost-bedded pack) space per cow was $6,8 \pm 2.2 \mathrm{~m}^{2} /$ cow (range of 3.56 to $10.18 \mathrm{~m}^{2} / \mathrm{cow}$ ). The depth of the bedded pack at the moment of farm visits was $25.6 \pm 9.4 \mathrm{~cm}$ (range from 15 to $40 \mathrm{~cm}$ ).

\section{Management}

Management practices applied in the farms included in this study was quite heterogeneous. However, the most commonly used technique can be described as follows. To start a compost-bedded pack a layer of $10-20 \mathrm{~cm}$ of organic bedding is distributed on the floor of the lying area. During the first 5-10 days the pack is not aerated and no bedding is added. After this starting period the surface of the bedded pack is stirred on a regular basis once or twice daily while cows are being

Table 1. Descriptive statistics for the herds' performance between September 2011 and September 2012.

\begin{tabular}{lccc} 
Parameter & Min & Mean(SD) & Max \\
Milk yield (kg/cow*day) & 24.8 & $30.8(3.05)$ & 35.2 \\
DIM & 184 & $209(29.1)$ & 273 \\
\hline 305 mature equivalent milk production $(\mathrm{kg})$ & 9205 & $10541(667)$ & 11458 \\
Milk fat (\%) & 3.43 & $3.67(0.17)$ & 3.88 \\
\hline Milk protein (\%) & 3.33 & $3.48(0.10)$ & 3.62 \\
SCC (cell*1000/mL) & 132 & $354(121.1)$ & 548 \\
\hline Age at firs calving (months) & 22 & $29(4.0)$ & 35 \\
Number of parity & 2.01 & $2.39(0.26)$ & 2.74 \\
\hline Calving interval (days) & 395 & $450(35)$ & 494 \\
Number of services per pregnancy & 1.84 & $2.67(0.47)$ & 3.53 \\
\hline
\end{tabular}


milked in the parlor. A layer of fresh dry bedding is added every $12 \pm 17$ days (range from 1 to 55 days) mainly to keep the moisture content of the pack under control. Most producers add a consistent amount of fresh dry materials only when the bedding particles start to adhere to the cows but in some dairies a smaller amount was added more frequently, up to once daily. The bedded pack area was completely cleaned out every $30 \pm 35$ days (range from 10 to 90 days) when the moisture content of the bedded pack exceeds a critical level at which cows start to sink deep into the pack and the aerations become difficult.

In 6 farms the pack was aerated once a day and twice a day in the remaining 4 , averaging 1.4 aeration per day. Typically a tractor provided with a tines cultivator was used to stir the bedded pack. The power of tractors used for cultivating the pack was $62 \pm 16.1 \mathrm{~kW}$ (range from 37 to $88 \mathrm{~kW}$ ). On average the pack was aerated at a depth of $19 \pm 7.6 \mathrm{~cm}$, ranging from 10 to $30 \mathrm{~cm}$. Stirring the pack required $41 \pm 47 \mathrm{~min} /$ day (range from 5 to $150 \mathrm{~min} /$ day) and the productivity of this operation resulted in $2610.9 \pm 2425.7 \mathrm{~m}^{2} /$ hour (range from 725 to $8006.5 \mathrm{~m}^{2} /$ hour). All the operations related to compost-bedded pack management (startup, aeration, bedding addition and barn cleaning) required $356 \pm 274$ hours/year (range from 136 to 1002 hours/year). By comparing the annual labor requirement for pack management with the number of cows housed in each barn, the annual labor per cow resulted in $4.2 \pm 2.1$ hours/cow*year (range from 1.2 to 6.7 hours/cow*year). Since the labor for pack cultivation primarily depended on the surface of bedded pack, a significant relationship $\left(R^{2}=0.505\right.$; $p$-value $\left.=0.048\right)$ was found between the space per cow and the annual labor requirement for pack management (Figure 1).

\section{Bedding}

In compost dairy barns included in this study dry sawdust and wood shavings (mainly from pine wood) are used for bedding. Seven producers used only sawdust while 3 preferred a mixture of sawdust and wood shavings. During winter one farmer tried to add a load of coconut fiber but he reported problems due to rapid rise in moisture content which resulted in a consistent loss of structure. In warm periods some producers successfully reused sun-dried manure coming from compost-bedded pack barns. The amount of fresh bedding materials needed was $875.2 \pm 469.7 \mathrm{~m}^{3} /$ year (range from 575 to $1600 \mathrm{~m}^{3} /$ year). Annual bedding requirement compared with the bedded area surface and the number of cows housed in each barn resulted respectively in $1.4 \pm 2.9$ $\mathrm{m}^{3} / \mathrm{m}^{2 *}$ year (range from 0.3 and $2.6 \mathrm{~m}^{3} / \mathrm{m}^{2 *}$ year) and $8.2 \pm 2.9$ $\mathrm{m}^{3} / \mathrm{cow}^{*}$ year (range from 3.2 and $13.4 \mathrm{~m}^{3} / \mathrm{cow}^{*}$ year).

The amount of bedding as well as the frequency whit which is added and the time between complete pack renovations strongly depended on season and weather conditions. In all farms included the consumption of bedding was concentrated in the winter period when the evaporation of water from the pack was limited due to low air temperature and high relative humidity. Most of the dairies did not add any bedding to the pack in the period between May and late September. Although climate plays a major role, also the bedded area space per cow affected the amount of bedding needed in compost dairy barns. Increasing the bedded area surface resulted in greater amount of bedding used to start-up the pack. On the other hand larger space per cow allowed to reduce consistently the need of bedding in the following phases. A clear tendency to inverse correlation $\left(\mathrm{R}^{2}=0.395\right.$; $\mathrm{p}$-value $\left.=0.051\right)$ was found between the space per cow and the annual amount of bedding used per cow (Figure 2).

\section{Pack temperature}

The temperature of the pack measured during summer was 29.6 $\pm 3.7^{\circ} \mathrm{C}$ (range from 24.2 to $33.4^{\circ} \mathrm{C}$ ). In the same period the air temperature inside the barn was $29.3 \pm 1.6^{\circ} \mathrm{C}$ (range from 27.3 to $31.4^{\circ} \mathrm{C}$ ).
During winter the temperature of the pack was $11.7 \pm 6.0^{\circ} \mathrm{C}$ (range from 6.4 to $21.6^{\circ} \mathrm{C}$ ) while the air temperature was $4.4 \pm 1.9^{\circ} \mathrm{C}$ (range from 2.3 to $7.2^{\circ} \mathrm{C}$ ). Both in summer and winter the temperatures of the pack were not sufficient to identify a composting process. However the difference between pack and air temperatures measured during winter indicated that pack was biologically active. In few barns, especially during summer, the temperature of the pack was lower than air temperature. Probably this was due to the intense evaporation of water from the surface of the pack.

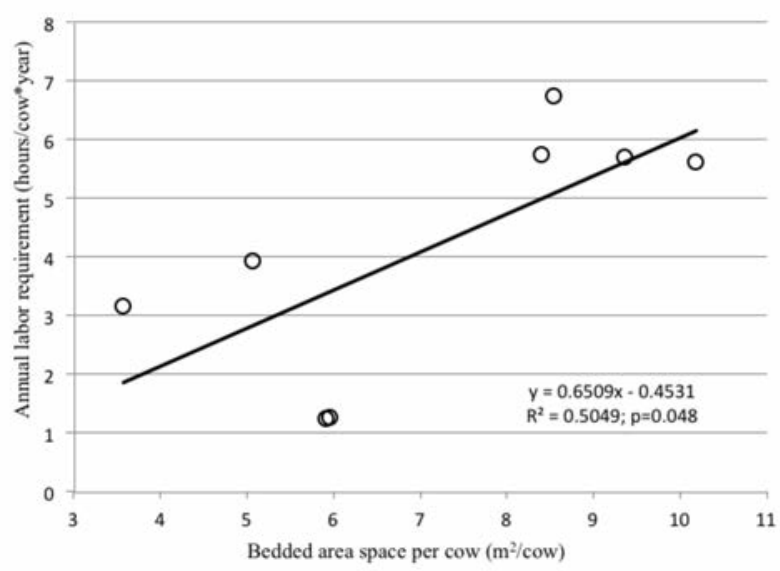

Figure 1. Scatter plot of the relationship between the bedded area space per cow and the annual labor requirement for pack management (data from 2 farms were not available).

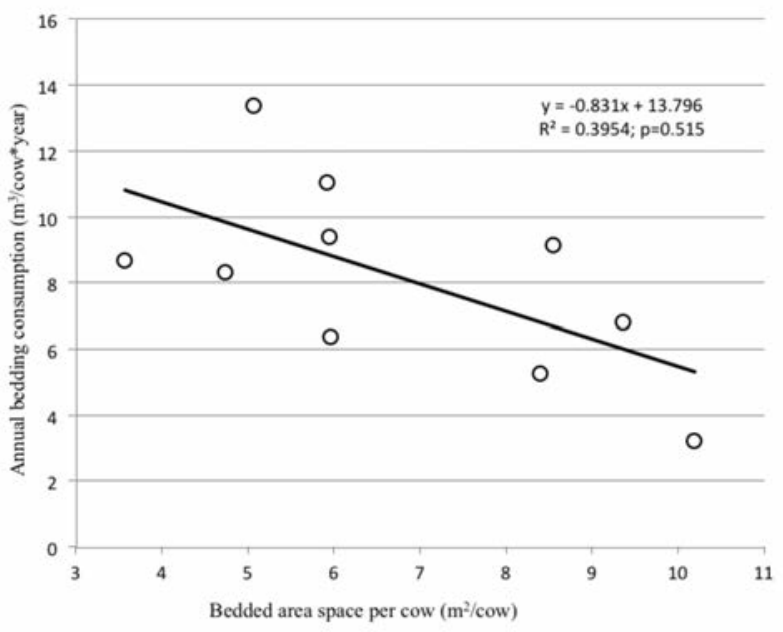

Figure 2. Scatter plot of the relationship between the bedded area space per cow and the annual amount of bedding used. 


\section{Producers' satisfaction}

Overall producers were satisfied with their compost-bedded pack barns. Almost all producers identified cows' welfare and legs and feet health as the main benefits of this alternative housing system. High satisfaction levels were also found towards udder health, fertility and manure management. Many farmers spontaneously remarked a reduced presence of flies in compost barns, especially during the summer period. Major concerns regard ease of management and costs. Results of the survey on producers satisfaction are summarized in Table 2.

\section{Discussion}

Many farmers shifted from deep straw-bedded yard to compost-bedded pack to reduce SCC. The satisfaction level towards this aspect leads to think the objective has been achieved. In dairies included in the current study the herd mean SCC was $354,000 \pm 121,100$ cells $/ \mathrm{mL}$. Other studies on compost dairy barns reported similar SCC. In a survey carried out in Kentucky the herd mean SCC was 318,000 cells/mL (Black $e t$ al., 2013). Barberg et al. (2007b) reported a mean SCC of 325,000 $\pm 172,000$ cells/mL for 12 herds housed in compost barns in Minnesota. In the same study a reduction in mastitis infection rate was found in 6 out of 9 herds after shifting to compost-bedded pack barns. Lobeck et al. (2011) compared welfare of dairy cows housed in compost barns and free stall barns finding no significant difference in mastitis infection rate. Although udder health in compost barns seems to be adequate, difficulties in keeping dry the pack could pose challenges towards cow cleanliness, especially during winter period. Many authors emphasized that a high hygiene level at milking and proper management of the pack are essential for achieving high quality milk in this housing system (Barberg et al., 2007b; Janni et al., 2007; Black et al., 2013).

Producers interviewed in the current study were widely satisfied with the increased welfare of cows housed in compost-bedded pack barns. Similarly Minnesota dairy farmers identified animal welfare as the main reason to build a compost barn (Barberg et al. 2007a) and increased cow comfort compared to free stalls was the most frequently cited benefit of this alternative housing system among dairy producers in Kentucky (Black et al., 2013). Experimental data confirmed that compost-bedded pack barns have positive impact on the welfare of dairy cows (Barberg et al., 2007b; Fulwider et al. 2007; Lobeck et al., 2011). However many authors remarked that cost and availability of bedding could limit the use of compost barns (Barberg et al., 2007a; Shane et al., 2010). Also Italian producers expressed quite clearly their concern about this issue.

In the compost barns included in the current study the annual amount of bedding used was $8.2 \mathrm{~m}^{3} / \mathrm{cow}^{*}$ year. Considering an average cost for dry sawdust of $18 € / \mathrm{m}^{3}$, the annual bedding cost resulted in 148 $€ /$ cow*year. Janni et al. (2007) estimated an annual bedding consumption in Minnesota compost barns of $19.6 \mathrm{~m}^{3} / \mathrm{cow}^{*}$ year and a total annual bedding cost of $181 \$ / \mathrm{cow}^{*}$ year. Although the annual cost for bedding was similar due to the difference in sawdust price, the amount of bedding used in Italian compost barns was sensibly lower than that used in Minnesota. Climate and weather conditions could partially explain the amount of bedding needed but pack management and barns' characteristics have to be considered as well.

The space per cow is considered by many authors as a key factor in compost-bedded pack barn management (Klaas and Bjerg, 2011). Janni et al. (2007) recommended a minimum pack area space per cow of 7.4 $\mathrm{m}^{2} /$ cow for a $540 \mathrm{~kg}$ cow. More recently researchers from Kentucky suggested that the optimal space per cow ranges from 9.3 to $10.2 \mathrm{~m}^{2} / \mathrm{cow}$
Table 2. Producers' satisfaction levels with compost bedded pack housing system in regards to different features.

\begin{tabular}{lccc} 
Feature & \multicolumn{2}{c}{$\begin{array}{c}\text { Satisfaction levela } \\
\text { Mean }\end{array}$} & Max \\
Animal welfare & 3 & 3,65 & 4 \\
Cow cleanliness & 2 & 3,00 & 4 \\
\hline Udder health & 3 & 3,25 & 4 \\
Claw and leg health & 3 & 3,50 & 4 \\
\hline Fertility & 2 & 3,13 & 4 \\
Longevity & 2 & 3,00 & 4 \\
\hline Milk yield & 2 & 3,00 & 4 \\
Ease of management & 2 & 2,88 & 4 \\
\hline Costs & 2 & 2,63 & 4 \\
Manure management & 2 & 3,25 & 4
\end{tabular}

aSatisfaction reported on a 4-point scale, from 1 (very dissatisfied) to 4 (very satisfied)

(Black et al., 2013). Considering the only bedded area, the space allotment in compost barns included in the current study was $6,8 \pm 2.2$ $\mathrm{m}^{2} /$ cow. Since an inverse relationship was found between the space per cow and the amount of bedding used per cow (Figure 2), increasing the space per cow should results in a reduction in bedding consumption. As a matter of fact, considering the only barns which had more than 8 $\mathrm{m}^{2} / \mathrm{cow}$ (n. 4) the average annual amount of bedding used and the annual cost for bedding resulted respectively in $3.0 \mathrm{~m}^{3} / \mathrm{cow}^{*}$ year and 54 $€ /$ cow $^{*}$ year. On the other hand an increase in the space per cow may result in an increase in labor requirement for pack aeration. The productivity of pack stirring operations varied considerably among compost barns included (from 725 to $8006.5 \mathrm{~m}^{2} /$ hour). Producers remarked that shape and dimensions of the barn strongly affected the amount of time needed to stir the pack. Regular shape of the bedded areas minimized the time required for aerating the pack.

The space per cow and the shape of the bedded area can affect significantly the costs for compost-bedded pack barns management. However even the temperature of the pack should be taken into account. The heat produced by the microbial activity into the pack increases the evaporation of water and thus reduces the amount of bedding needed to maintain dry the pack (Janni et al., 2007). Smits and Aarnink (2009) calculated that the evaporation of water from a bedding that is composting is higher than from a non-composting pack. Black et al. (2013) fount that in Kentucky compost barns the ideal pack temperature is between 43 and $60^{\circ} \mathrm{C}$. Nevertheless high pack temperature seems to be necessary only in compost barns with relatively high animal density (7.5-12.5 $\mathrm{m}^{2} / \mathrm{cow}$ ) and in cold climates, especially during winter. In Israeli climatic conditions by providing each cows with at least $15 \mathrm{~m}^{2}$ it was possible to maintain dry pack during the whole year, even though the heat generation was limited (Klaas et al. 2010). In compost barns included in the current study the temperatures of the pack (winter: $11.7 \pm 6.0^{\circ} \mathrm{C}$; summer: $29.6 \pm 3.7^{\circ} \mathrm{C}$ ) and the bedded area space per cow $\left(6,8 \pm 2.2 \mathrm{~m}^{2} / \mathrm{cow}\right)$ seem to be insufficient to allow adequate evaporation from the pack, especially during winter.

Low bacterial activity in the pack could be explained by high animal density which leads to excessive bedding moisture content and thus limits the growth of aerobic bacteria. Black et al. (2013) found that maximum pack temperatures tend to be achieved when the bed moisture content is between 40 and $60 \%$. Moreover in order to keep the heat produced into the pack, relatively high pack depth are needed. Experiences from the Netherlands indicated that a layer of at least 50 $\mathrm{cm}$ is needed to avoid excessive heat dissipation during pack stirring 
(Galama, 2011). In addition higher pack depth allows to store manure into the barn for longer periods reducing the need of external storage and the labor required for pack renovations. In compost barns included in the current study the pack depth ranges from 15 to $40 \mathrm{~cm}$. Most producers reported difficulties in increasing the pack depth because the bed moisture content raised too rapidly and cows sunk deep into it. In Italian compost barns lower animal densities seem to be necessary to maintain adequate pack moisture content and decrease the amount of bedding needed, especially during winter. Further studies are needed to identify the ideal space per cow and develop management recommendations for compost dairy barns in Italian climate.

\section{Conclusions}

Italian compost-bedded pack barns may represent an effective solution for housing dairy cows. Producers identified animal welfare as the main benefit of this system and overall they appeared to be very satisfied. Nevertheless concerns about the cost of bedding led to think that pack management and barns' characteristics have not been optimized yet. Results obtained confirmed that animal density is a key factor in compost-bedded pack barns.

\section{References}

Barberg A.E., Endres M.I., Janni K.A. 2007a. Compost dairy barns in Minnesota: a descriptive study. Appl. Eng. Agric. 23(2):231-238.

Barberg A.E., Endres M.I., Salfer J., Reneau J. 2007b. Performance and welfare of dairy cows in an alternative housing system in Minnesota. J. Dairy Sci. 90(3):1575-83.

Black R., Bewley J., Taraba J., Day G., Damasceno F.A. 2013. Kentucky compost-bedded pack barn project. Cooperative extension service, University of Kentucky, College of agriculture. Lexington, KY, 40546 .
Enders M.I., Barberg A.E. 2007. Behaviour of dairy cows in an alternative bedded-pack housing system. J. Dairy Sci. 90(9):4192-4200.

Fulwider W.K., Grandin T., Garrick D.J., Engle T. E., Lamm W. D., Dalsted N. L., Rolling B. E. 2007. Influence of free-stall base on tarsal joint lesions and hygiene in dairy cows. J. Dairy Sci. 90(7):3559-3566.

Galama P. 2011. Prospects for bedded pack barns for dairy cattle. WUR Livestock Research, Wageningen, NL.

Janni K.A., Endres M.I., Reneau J.K., Schoper W.W. 2007. Compost dairy barn layout and management recommendations. Appl. Eng. Agric. 23(1):97-102.

Klaas I.C., Bjerg B. 2011. Compost barns - an alternative housing system for dairy cows? CAB Reviews: Prospectives in Agriculture, Veterinary Science, Nutrition and Natural Resouces. 45(6):1-9.

Klaas I.C., Bjerg B., Friedmann S., Bar D. 2010. Cultivated barns for dairy cows - an option to promote cattle welfare and environmental protection in Denmark? Dansk Veterinærtidsskrift. 93(9):20-9.

Lobeck K.M., Endres M.I., Shane E.M., Godden S.M., Fetrow J. 2011. Animal welfare in cross-ventilated, compost-bedded pack, and naturally ventilated dairy barns in the upper Midwest. J. Dairy Sci. 94(11):5469-5479.

Ofner-Schröck E., Zähner M., Huber G., Guldimann K., Guggenberger T., Gasteiner J. 2013. Kompoststall - funktionell und tiergerecht? Bautagung Raumberg-Gumpenstein. 2013, 15-22.

R Development Core Team. 2011. R: A language and environment for statistical computing. R Foundation for Statistical Computing, Vienna, Austria. ISBN 3-900051-07-0, URL http://www.Rproject.org/.

Shane E.M., Endres M.I., Janni K.A. 2010. Alternative bedding materials for compost bedded pack barns in Minnesota: a descriptive study. Appl. Eng. Agric. 26(3):465-73.

Smits M.C.J., Aarnink A.Y.A. 2009. Verdamping uit ligbodems van vrijloopstallen; oriënterende modelberekeningen. Rapport 230. Animal Sciences Group. Wageningen UR.

Ventura P.G. 2011. Un modello innovativo per le stalle europee. Stalle da latte. 29:30-32.

Vighi P., Uberti M., Calamari L. 2009. Più benessere per le bovine con l'erpicatura della lettiera. Terra e Vita. 24:43-46 